\title{
Masters of War: Rivals' Product Innovation and New Advertising in Mature Product Markets
}

\author{
Andrea Fosfuri, Marco S. Giarratana \\ Department of Business Administration, Universidad Carlos III de Madrid, Calle Madrid, 126, 28903 Getafe, \\ Madrid, Spain \{andrea.fosfuri@uc3m.com, marco.giarratana@uc3m.es\}
}

\begin{abstract}
$\mathrm{W}^{\mathrm{c}}$ e investigate the impact of rivals' product innovation and new advertising on a firm's financial market value in mature product markets. Our test bed is the carbonated soft drink market between 1999 and 2003, a period characterized by a near duopoly between Coca-Cola and Pespi. Empirically, we focus on new product announcements as a proxy of product innovation and on filed trademarks as a measure of new advertising. We find that rival product announcements decrease a firm's financial market value, and that rival filed trademarks increase it. Finally, we find that the effect of new advertising is channeled through market size dynamics, while that of product innovation operates through market share dynamics. Results are robust across different estimation techniques (event study, Tobin's q) and model specifications.
\end{abstract}

Key words: product innovation; advertising; firm value; rivalry; trademarks

History: Accepted by Jagmohan S. Raju, marketing; received March 20, 2007. This paper was with the authors $4 \frac{1}{2}$ months for 2 revisions. Published online in Articles in Advance November 18, 2008.

\section{Introduction}

What determines a firm's financial market value is valuable information for economic actors like shareholders, investors, and managers whose rewards are directly linked to the firm's stock market performance. In mature product markets, in which demand and product standards are consolidated, a firm's financial market value should be influenced less by exogenous factors (demand shocks, technology paradigm shifts, industry shake-outs, etc.) and more by managerial actions (Andrews and Smith 1996).

In addition, in mature product markets, because of the small number of well-established competitors, actions of rival firms become relatively more important for the understanding of a firm's financial market value. In fact, rival actions are more visible, and their effects are both more sizable and easier to single out. The empirical literature on this topic is, however, rather underdeveloped. A recent paper by McGahan and Silverman (2006) focuses on the effect of patents granted to competitors. Other scholars have looked at competitors' radical product innovations (Aboulnasr et al. 2008), alliances (Das et al. 1998), and price changes (Chen and MacMillan 1992). To the best of our knowledge, little research has been conducted on the effect of rival moves along non-price dimensions of the marketing mix-typically relevant in many mature product categories-on a firm's financial market value.

Our paper fills this lacuna. Specifically, we investigate how rival moves in product innovation and new advertising affect a firm's stock market performance in a mature product market beyond own firm moves. A priori, the expected effect is not clear-cut, because some rival actions could increase a firm's financial market value while others might dampen it (Bayus and Putsis 1999, Kadiyali et al. 1999). We argue that a good strategy to dissolve this ambiguity is to disentangle those rival actions that redistribute market shares (market share dynamics) from those that alter total demand (market size dynamics).

Empirically, we investigate our surmises in the carbonated soft drink (CSD) industry from January 1999 to December 2003, a $\$ 66$ billion industry in the United States alone in 2005 (Yoffie 2007). The choice of this market makes a natural experiment possible: During the sample period, the CSD market was virtually a mature duopoly (Coca-Cola and Pepsi controlled more than $75 \%$ of total sales) characterized by relative price stability, little growth in demand, and the absence of exogenous shocks (Dubé 2004). The duopoly condition allows us to investigate with greater precision the effects of strategic actions and reactions on the two competitors' financial market value. Moreover, because in the CSD industry prices are not major tools of competition, we are able to isolate more effectively the impact of product innovation and new advertising. ${ }^{1}$ It is worth noting that Coca-Cola and Pepsi together invest more than

${ }^{1}$ Coca-Cola and Pepsi make most of their profits by selling concentrate to independent bottlers. Interesting enough, during the period under study, CSD retail prices have remained stable, while 
$\$ 3$ billion each year in new product development and advertising.

Our empirical results show that rival product innovation has a negative impact on a firm's financial market value, while rival new advertising has a positive effect. These two strategic actions affect financial market value through different channels. While rival new advertising affects the firm's financial market value through total demand (market size dynamics), rival product innovation acts directly on the distribution of market shares (market share dynamics).

The paper makes the following contributions to the literature. First, we enrich the evidence on the impacts of marketing actions on a firm's financial market value, which is somewhat less extensive than that focused on other competitive moves, such as alliances or research and development (R\&D) investments. Most of the existing research is focused on measuring how a change in advertising expenditures affects stock prices (e.g., Erickson and Jacobson 1992, Cheng and Chen 1997). Some notable exceptions are Rao et al. (2004), who analyze the relationship between branding strategy and the intangible value of a corporation; Mizik and Jacobson (2003), who focus on the financial market impact of shifts in strategic emphasis; Lane and Jacobson (1995), who explore the role of brand attitude and familiarity on the stock market reactions to brand extension announcements; and Pauwels et al. (2004) and Srinivasan et al. (2009), who investigate the relationship between sales promotions, product innovation, and firm value in the automobile industry.

Most notably, our paper constitutes one of the few studies that highlight the impact of rival marketing moves on a firm's financial market value (for product announcements, see Chen et al. 2005). Theoretically, product innovation and new advertising can work as either defensive or offensive strategic tools (Bayus and Putsis 1999, Kadiyali et al. 1999, Shaffer and Zhang 2002). Our evidence suggests that in the case of Coca-Cola and Pepsi, the defensive nonthreatening effect prevails for new advertising, the aggressive effect dominates for product innovation. Although this finding might be specific to the CSD market, the idea that new advertising is less aggressive than product innovation can be a more general insight.

Our contribution in terms of measurement is also worth mentioning. We use trademarks filed at the U.S. Patent and Trademark Office (USPTO) as a proxy for new advertising. Trademarks, similarly to patentsa commonly employed measure of innovation-are intellectual property rights. Differently from patents,

concentrate prices have slightly increased (Yoffie 2007). In fact, prices of concentrate are negotiated through long-term contracts and remain mostly fixed for a long while. however, trademarks are not granted "on the basis of nonobviousness, inventiveness in the face of prior art and the potential for industrial application" (Mendonca et al. 2004, p. 1387). Whereas patents are used to protect innovation, trademarks are filed to secure legal protection of brand names, recognizable designations, and symbols for goods and services, as well as firms' identities. Trademarks can be conceived as one of the possible outcomes of a firm's advertising activity. ${ }^{2}$ From an empirical viewpoint, trademarks combine high time frequency with a reliable good and service description, so that it is possible to measure the precise advertising output in a given product category. Compared to standard accounting measures, this allows a better match with the promotion process, which is characterized by pulsing, i.e., firms systematically switch promotion on and off at a high frequency (Ofek and Sarvary 2003). Moreover, even if correlated with advertising expenditures, trademarks constitute an output measure that is more likely to affect directly a firm's financial market value, compared to input variables. For example, Seethamraju (2003) uses trademarks as a proxy for a firm's intangible marketing assets.

The next section lays down the theoretical background and defines our hypotheses. Section 3 briefly describes the CSD market; $\S 4$ presents the data and our empirical methods, shows the results, and discusses several robustness checks. Section 5 concludes the paper.

\section{Theoretical Background and Hypotheses}

In mature product markets, where design standards are well established, competition is more functional and strategic, and typically revolves around improvement of the existing products and processes and on enhanced marketing activity (Chandler 1994). A growing stream of the literature has attempted to analyze the impact of product innovation and new advertising on firm financial market value (Bayus et al. 2003, Rao et al. 2004, Srinivasan et al. 2009). ${ }^{3}$ There are several intertwined forces at play, which

\footnotetext{
${ }^{2}$ Mendonca et al. (2004) suggest that trademarks can be used as an indicator of innovation activity. Instead, we believe that trademarks serve better as an indicator of advertising activity for several reasons. First, a trademark can be legally granted without an underlying innovation. Second, even when it is associated with a new product or service, a trademark constitutes the outcome of a marketing effort aimed at increasing the protection of the innovation. Finally, as suggested by interviews with marketing executives at Pepsi and Coca-Cola, most trademarks are not associated with new products or services, but with new advertising campaigns. For a similar interpretation, see Seethamraju (2003).

${ }^{3}$ Product innovations modify observable characteristics, such as size, shape, color, weight, design, material, reliability, and taste,
} 
increase the complexity of the analysis. Both product innovation and new advertising are likely to positively affect the financial market value of the firm by triggering business stealing from competitors (Kekre and Srinivasan 1990) and/or expanding demand by either stimulating purchase acceleration (Chaudhuri and Holbrook 2001) or attracting new customers (Lancaster 1984). On the other hand, some authors have argued that these positive effects must be weighted against the risk of jeopardizing existing income streams (Conner 1998). Most of the empirical works have, however, found a positive impact of a firm's actions along these two dimensions on its financial market value. Surprisingly enough, the impact of rivals' product innovation and new advertising on a firm's financial market value has received disproportionately less attention, if any. ${ }^{4}$ Thus our theoretical argument below will focus on the effect of rivals' actions only. This choice is not meant to deny the importance of our actions, but simply to sharpen the exposition and preserve conciseness.

To structure the discussion, let $v_{i t}$ be the financial market value of firm $i$ at time $t$; that is, the net present value of its future stream of profits. Mahajan et al. (1993) and Nguyen and Shi (2006), among others, argue that the relationship between $v_{i t}$ and rivals' actions depends on the interaction of two effects: market substitution (market share dynamics) and market expansion (market size dynamics). Other things being equal, financial market value is likely to increase if the firm attains a larger market share and/or if total demand expands. In the following arguments, the effects of rival product innovation and new advertising on a firm's financial market value are channeled through these two different avenues.

In formulating our hypotheses, we do not examine other marketing actions like price and price promotions that might affect a rival's financial market value. To empirically control for this additional source of heterogeneity, we focus on a specific context in which price and price promotions are barely used by competitors. Thus, pricing can safely remain in the background.

\subsection{Product Innovation}

Because of well-established product standards, product innovations in mature product industries tend to be incremental or marginal. We analyze here the

which are relevant to customers' preferences and condition their choices. Advertising is built on a complex constellation of psychological attributes that the consumer assigns to purchasing, owning, and consuming a particular product. To a great extent, advertising creates brand power that influences and reinforces customer perceptual connections among products, identity, and lifestyle (Upshaw 1995).

${ }^{4}$ A notable exception is Chen et al. (2005). impact of a rival's efforts to expand, modify, and deepen its product offerings on firm $i$ 's financial market value. First, consider firm i's market share. In almost any model of product differentiation, a larger number of varieties produced by a rival reduces competitors' market shares (e.g., Champsaur and Rochet 1989, Kekre and Srinivasan 1990). In fact, as long as some customers are substituting firm $i$ 's products for rival new offerings, then the impact of a rival's move on a firm's market share is negative.

Concerning market size dynamics, first, by expanding its set of product features, a firm can induce greater demand among existing customers. Second, and more important, by adding new product varieties, a firm can attract customers who try the product for the first time. New customers usually exhibit little brand loyalty and may later spread across different brands, the so-called churn demand (Neslin et al. 2006). This implies that a firm's new product introductions could increase industry demand, with some of this increment spilling over to its rivals. For instance, Mahajan et al. (1993) have shown that the introduction of the instant cameras by Kodak expanded the market by $37 \%$, benefiting also its rival, Panasonic.

In mature product markets, it is less likely that product innovations will end up attracting new and inexperienced consumers who might first try a product and later reallocate their demand toward competing brands. This follows the current view in the literature: It is radical, not marginal or incremental, product innovation that significantly influences market size dynamics (e.g., Aboulnasr et al. 2008). Similarly, Mahajan et al. (1993) argue that the market expansion effect of a new product introduction is more likely to happen early in the process of market evolution.

In sum, product innovation by a rival is likely to decrease a firm's market share, thus reducing its financial market value, other things being equal (price, costs, etc.). In mature product markets, this negative effect is unlikely to be counterbalanced by an increment in total demand.

Hypothesis 1. In mature product markets, the net effect of rival product innovation on a firm's financial market value is negative.

\subsection{New Advertising}

Rival new advertising might also affect both firm $i$ 's market share and total demand. The literature classifies advertising in two categories: generic and brand advertising (Bass et al. 2005), which affect market size and market share dynamics differently.

Generic advertising boosts primary demand by attracting new consumers (Berndt et al. 1997), increasing per capita consumption of the product, 
and lengthening the product life cycle (Friedman and Friedman 1976, Krishnamurthy 2000). Lancaster (1984) claims that market size dynamic is the most common effect of advertising. Greater demand benefits all incumbent firms, thus rival generic new advertising is likely to increase a firm's financial market value.

Rival brand advertising directly influences firm $i$ 's market share. In fact, brand advertising can increase the probability that a customer will change his or her purchase decision. It provides consumers with information about the brand's value proposition that differentiates it from its competitors, thereby encouraging consumers of other brands to move to the advertised product (Krishnamurthy 2001). However, in mature product markets, the product design is well established and consumers tend to be well informed and sophisticated. Information channeled through advertising is less relevant, and brand loyalty is consolidated and more difficult to circumvent. For instance, Parsons (1975) and Tellis and Fornell (1988), among others, report that consumer response to brand advertising is lower in later stages of the product life cycle.

Because brand identity is well established in mature product markets, brand advertising can also increase the perceived differentiation among competing brands (Lancaster 1984). The more differentiated the brands are in the eyes of the consumers, the greater the brand loyalty and the more inelastic demand will be. Thus all firms might benefit of increased market power as a consequence of brand advertising.

Finally, in mature product markets, advertising can be used to endogenously increase barriers to entry (Sutton 1998). Thus, a rival's advertising might signal an attempt to make entry by potential competitors much more difficult and expensive. To compete on equal foot, new entrants must undertake similar sunk investments in advertising, which, given their initial small scale, would push their average cost well above that of existing firms. All incumbents would benefit if barriers to entry an industry are raised.

These arguments lead to our second hypothesis.

Hypothesis 2. In mature product markets, the net effect of rival new advertising on a firm's financial market value is positive.

\section{Market Background: CSD Industry}

A CDS consists of a flavor base, a sweetener, and carbonated water. The production and distribution of CSDs involve four major participant groups: suppliers of inputs, concentrate producers, bottlers, and retail channels. A concentrate producer blends a few raw materials that, for most regular colas, consist of caramel coloring, phosphoric or citric acid, natural flavors, and caffeine. Such inputs are produced at competitive prices. Bottlers purchase concentrate, add carbonated water and high fructose corn syrup, bottle or can the CSD, and deliver it to customer accounts. The CSD industry grew in the United States at approximately 3\% per year over the period 1970 2000 with demand flattening over the last years.

Among concentrate producers, Coca-Cola and Pepsi controlled $75.6 \%$ and $75.8 \%$ of the U.S. CSD market in sales volume in 1999 and 2003, respectively. Cadbury Schwepps (approximately 14\%) and private labels (approximately 10\%) accounted for the remaining share of the U.S. CSD market. Coca-Cola was formulated in 1886, and Pepsi-Cola in 1893. Coca-Cola was the uncontested leader in the early history of the CSD market, with a 50\% market share in 1950. During the 1960s, Coca-Cola and Pepsi began to experiment with new cola and noncola flavors and a variety of packaging options, abandoning their traditional single-product strategy.

Although Coca-Cola and Pepsi have aggressively competed for market share, they have often avoided direct price competition (pretax profits of the order of $30 \%$ in the late 1990s). Thus, announcements of increases in concentrate price by one company are often followed immediately by upward adjustments by the rival. For instance, both firms raised concentrate prices throughout the 1980s and early 1990s, even if the real (inflation-adjusted) retail prices for CSD decreased. According to Roger Enrico, former CEO of Pepsi-Cola, "the warfare must be perceived as a continuing battle without blood.... If the CocaCola company didn't exist, we'd pray for someone to invent them" (Yoffie 2007, p. 1). The price of concentrate is negotiated with the bottlers through longterm agreements. The bottlers, who have exclusive territories, take care of distributing cans and bottles to the retailers, except in the case of fountain outlets (McDonald, Subway, etc.).

The two firms are instead aggressively competing on nonprice dimensions of the marketing mix, i.e., product innovation and advertising. In the CSD industry, new product introduction refers to a change in the physical characteristics of the product: flavors, ingredients, colors, packaging, etc.-all marginal or incremental innovations. The importance of advertising is documented by the important investment in branding and trademarks over time, usually with innovative and sophisticated advertising campaigns. Coca-Cola filed for its first trademark in 1927 and at the end of 2004 had been granted 1,105 trademarks. Pepsi registered its first trademark in 1907 and at the end of 2004 had filed 1,402 trademarks. In the year 2000, Coca-Cola spent more than \$200 million advertising its flagship brand, "Coke Classic" (Yoffie 
2007). From the annual reports, Coca-Cola advertising expenditures topped $\$ 1.8$ billion in 2002 and $\$ 1.9$ billion in 2003. Pepsi shows similar amounts (\$1.6 billion and $\$ 1.5$ billion). By contrast, private labels do not play this game.

\section{Data and Empirical Analysis}

\subsection{Variables of Theoretical Interest}

The two variables of theoretical interest are product innovation and new advertising. We measure these two variables with the announcements of new product introductions and with trademarks filed at the USPTO, respectively. The market for soft drinks can be divided into two main niches; namely, carbonated soft drinks (Coke, Pepsi, Sprite, Fanta, Mountain Dew, etc.) and noncarbonated soft drinks (juices, milky and energy drinks, tea, coffee, water, etc.). Coca-Cola and Pepsi operate in both niches. But because up until 2003, CSDs still accounted for substantially more than $50 \%$ of both firms' total sales (close to $80 \%$ for CocaCola), we focus on the CSD niche, where the two companies maintained a stable duopoly. We, however, control for their activity outside CSD.

Product introduction data come from Infotrac's Promt database, which, from a large set of trade journals, magazines, and other specialized publications, reports several categories of events like product introductions classified by SIC codes all around the world (although a U.S. bias might exist in the database). This database is the new version of the old Predicast database, which has been used extensively in the literature (e.g., Pennings and Harianto 1992). We search for all press articles that are classified as a "product announcement," a "new product release," or a "product introduction" for Coca-Cola or Pepsi between January 1999 and December 2003. Then, from each of these articles, we extract the date of product introduction, and we use the text and the precise SIC code of the article to select only those products introduced in the CSD niche. ${ }^{5}$ By and large, product announcements can be assigned to two categories: (1) new products (e.g., Cherry Mountain Dew, Lime Diet Coke, etc.) and (2) new packages, cans, or bottles of existing products (e.g., limited edition, silver-colored, plastic, 2-liter bottle, etc.). Our $79.4 \%$ of product introductions belong to this second category.

Trademarks are combinations of words, phrases, symbols, or designs that identify and distinguish the source of the goods or services of one party from those of others (http://www.uspto.gov). Firms can register as a trademark a new name, jingle, slogan,

\footnotetext{
${ }^{5}$ Precisely, we excluded tropical/milky and other types of juices, tea/coffee infusions, water, energetic/vitamin/sport drinks, and yogurts.
}

new image, or logo ("can't leave home without it"). ${ }^{6}$ Trademarks are employed to legally protect brand names, recognizable designations and symbols for goods and services, as well as firms' identities. Trademarks aim to place a connection in the mind of the consumer between a product or service and its level of quality (Seethamraju 2003). Interviews with executives at Coca-Cola and Pepsi have suggested that trademarks are also a crucial step in new advertising campaigns. For example, October 25, 2004, Coca-Cola filed for the trademark make it real, which the USPTO granted with the number 78,505,276. Randy Ransom, senior vice-president for marketing at Coca-Cola North America, commented: "The new campaign, called make it real, attempts to take the two-yearold [...] 'Coca-Cola Real' campaign to a new level." Many industry observers applauded the Real campaign for making strides in connecting with younger consumers (Wall Street Journal 2005, p. 14). The above reasons in addition to the higher frequency data availability make trademarks a valuable indicator of new advertising output.

We do not have information about trademarks registered outside the United States, which, given the importance of international markets for Coca-Cola and Pepsi, constitutes a limitation of the present work. It is true, however, that for most international advertising initiatives, both companies start their protection strategy at the USPTO.

We download all trademarks whose owner is CocaCola or Pepsi with filing dates between January 1999 and December 2003. Looking at the goods or services description, we select only the CSD-related trademarks.

It is worth noting that the two firms customarily concentrate trademarks filing in different periods of the year: Coca-Cola during the Christmas holidays and Pepsi during the summer holidays. Indeed, the correlation between the time series of Coca-Cola and Pepsi trademarks is only 0.126 , not significant at the $10 \%$ level. Note also the large standard deviation of the trademarks variable (shown in Table 2). It is difficult to observe this rich variation from accounting data alone. In fact, in the period 1999-2003, the two firms show an average growth rate of advertising expenses of only $1.1 \%$, with a standard deviation of $0.8 \%$. These figures suggest that (1) it is less likely that the number of trademarks is demand driven, thus attenuating potential endogeneity concerns and

\footnotetext{
${ }^{6}$ U.S. trademark owners pay different types of fees for each class of goods or services for which a trademark is registered, and they have to prove periodically that they are using the trademark in the U.S. market. The front page of the trademark file provides useful information-e.g., the owner's name and address, the date when a complete application was received by the USPTO (filing date), and the goods or services description.
} 
(2) trademarks allow for a more fine-grained analysis than advertising expenditures do.

In what follows, we first quantify empirically the impact of rival product announcements and filed trademarks on a firm's financial market value using both an event study approach and a Tobin's q regression, and then we explore more deeply the channels through which these marketing actions affect a firm's financial market value, i.e., market size and market share dynamics.

\subsection{An Event Study Regression}

We follow the model of Austin (1993), which is specifically suited for patent data and similar intangible assets. That is, we employ the capital asset pricing model in which the returns to firm equity in excess of the risk-free return are explained by returns to a value-weighted market index (net of the risk-free rate). We also control for the variables suggested by Fama and French (1992) to allow risk to depend not only on beta but also on size and "book-to-market" factors. We estimate a daily regression for the sample period (January 1999-December 2003). The "excess return" on a firm's equity is defined as the portion of the firm's $n$-day "event window" returns not explained by this model (i.e., the residual).

The modified model reads as follows:

$$
\begin{aligned}
\left(r_{i t}-r f_{t}\right)= & \alpha+\beta_{1}\left(r m k t_{t}-r f_{t}\right)+\beta_{2} S M B_{t} \\
& +\beta_{3} H M L_{t}+\Sigma_{\eta} \delta_{\eta} D_{\eta t}+\varepsilon_{i t},
\end{aligned}
$$

where $r_{i t}$ is the return on shares of firm $i$ over the time $t$ window. Data are from Yahoo!Financial. From the actualized data set of Fama and French (1992) ${ }^{7}$ we compute: $r f_{t}$, the risk-free rate of return at time $t$; $r m k t_{t}$, the return on all firms in NYSE, AMEX, and NASDAQ at time $t ; S M B_{t}$, the Fama and French's (1992) index of small versus big capitalization at time $t ; H M L_{t}$, the Fama and French's (1992) index of high versus low book/price ratio at time $t$.

$D_{\eta t}$ is a dummy variable equal to one if event $\eta$ occurs at time $t$. We have two main events: DproDUCTRIVAL (the rival has released a new product) and DTRADEMARKRIVAL (the rival has filed a new trademark). We also add as controls DproductFirm (the firm has released a new product), DTRADEMARKFIRM (the firm has filed a new trademark), and a firm dummy (FIRM, zero for Coca-Cola, one for Pepsi). $\alpha$ is the constant and $\varepsilon_{i t}$ the random error term. To eliminate noise and potential omitted variable bias, only product announcements and trademarks that did not coincide with other events (e.g., earnings announcements, changing relationships with bottlers

${ }^{7}$ Available at http://mba.tuck.dartmouth.edu/pages/faculty/ken. french/ftp/F-F_Research_Data_Factors_daily.zip.

\begin{tabular}{|c|c|c|c|c|c|c|}
\hline \multirow[b]{2}{*}{ Variable } & \multirow[b]{2}{*}{ Mean } & \multirow[b]{2}{*}{ Std. dev. } & \multicolumn{4}{|c|}{ Window of days } \\
\hline & & & $-5+5$ & $-3+3$ & $-1+1$ & 0 \\
\hline $\begin{array}{l}\text { Dependent variable } \\
r_{i t}-r f_{t}\end{array}$ & -0.013 & 0.020 & & & & \\
\hline \multicolumn{7}{|c|}{ Fama and French (1992) controls } \\
\hline$r m k t_{t}-r f_{t}$ & -0.015 & 1.344 & $\begin{array}{l}0.005^{* *} \\
(0.000)\end{array}$ & $\begin{array}{l}0.003^{* *} \\
(0.000)\end{array}$ & $\begin{array}{l}0.004^{* *} \\
(0.000)\end{array}$ & $\begin{array}{l}0.006^{*} \\
(0.000)\end{array}$ \\
\hline$S M B_{t}$ & 0.038 & 0.731 & $\begin{array}{l}0.007^{* *} \\
(0.001)\end{array}$ & $\begin{array}{l}0.004^{* *} \\
(0.001)\end{array}$ & $\begin{array}{l}0.003^{* *} \\
(0.001)\end{array}$ & $\begin{array}{l}0.004^{*} \\
(0.000)\end{array}$ \\
\hline$H M L_{t}$ & 0.022 & 0.830 & $\begin{array}{c}-0.004^{* *} \\
(0.001)\end{array}$ & $\begin{array}{c}-0.004^{* *} \\
(0.001)\end{array}$ & $\begin{array}{c}-0.005^{* *} \\
(0.001)\end{array}$ & $\begin{array}{r}-0.005^{*} \\
(0.001)\end{array}$ \\
\hline FIRM & 0.500 & 0.500 & $\begin{array}{l}0.009^{* *} \\
(0.001)\end{array}$ & $\begin{array}{r}0.004^{*} \\
(0.002)\end{array}$ & $\begin{array}{c}0.001 \\
(0.001)\end{array}$ & $\begin{array}{c}0.002 \\
(0.003)\end{array}$ \\
\hline$\alpha$ & & & $\begin{array}{c}-0.021^{* *} \\
(0.000)\end{array}$ & $\begin{array}{c}-0.019^{* *} \\
(0.001)\end{array}$ & $\begin{array}{c}-0.014^{* *} \\
(0.001)\end{array}$ & $\begin{array}{r}-0.013^{*} \\
(0.002)\end{array}$ \\
\hline \multicolumn{7}{|l|}{ Dummy event } \\
\hline DPRODUCTRIVAL & 0.041 & 0.199 & $\begin{array}{r}-0.006^{*} \\
(0.004)\end{array}$ & $\begin{array}{l}-0.005^{* *} \\
(0.002)\end{array}$ & $\begin{array}{c}-0.005^{* *} \\
(0.002)\end{array}$ & $\begin{array}{r}-0.008^{*} \\
(0.001)\end{array}$ \\
\hline DTRADEMARKRIVAL & 0.023 & 0.150 & $\begin{array}{c}0.004 \\
(0.004)\end{array}$ & $\begin{array}{c}0.004 \\
(0.003)\end{array}$ & $\begin{array}{l}0.004^{*} \\
(0.002)\end{array}$ & $\begin{array}{l}0.005^{*} \\
(0.001)\end{array}$ \\
\hline DPRODUCTFIRM & 0.041 & 0.199 & $\begin{array}{c}0.008 \\
(0.006)\end{array}$ & $\begin{array}{r}0.007^{*} \\
(0.004)\end{array}$ & $\begin{array}{l}0.007^{* *} \\
(0.003)\end{array}$ & $\begin{array}{l}0.010^{*} \\
(0.002)\end{array}$ \\
\hline DTRADEMARKFIRM & 0.023 & 0.150 & $\begin{array}{c}0.006 \\
(0.005)\end{array}$ & $\begin{array}{c}0.006 \\
(0.005)\end{array}$ & $\begin{array}{l}0.007^{* *} \\
(0.004)\end{array}$ & $\begin{array}{l}0.007^{*} \\
(0.003)\end{array}$ \\
\hline Observations & & & 2,816 & 2,816 & 2,816 & 2,816 \\
\hline$R^{2}$ & & & 0.093 & 0.092 & 0.102 & 0.114 \\
\hline Adj. $R^{2}$ & & & 0.091 & 0.091 & 0.099 & 0.101 \\
\hline
\end{tabular}

Table 1a Robust OLS Estimation of Equation (1)

Notes. Robust Huber-White estimator of variance. Event day regression in the sample period 1999-2003.

${ }^{*} 0.1$ significance; ${ }^{* *} 0.05$ significance.

Table 1b U.S. Dollar Changes (in Millions) in Firm Market Capitalization According to an Event (Average Values of Share Outstanding and Share Price 1999-2003)

\begin{tabular}{lrrr}
\hline Event & & & Coca-Cola + \\
& Coca-Cola & Pepsi & \multicolumn{1}{c}{ Pepsi } \\
\hline Coca-Cola announces a new product (1) & 908.4 & -352.8 & 555.6 \\
Pepsi announces a new product (2) & -648.9 & 493.9 & -154.9 \\
Product introduction $(1+2)$ & 259.5 & 141.1 & \\
Coca-Cola files a trademark (3) & 882.5 & 282.3 & $1,164.7$ \\
Pepsi files a trademark (4) & 479.8 & 519.1 & 998.9 \\
Trademark introduction $(3+4)$ & $1,362.3$ & 801.3 & \\
\hline
\end{tabular}

and fountain accounts, corporate initiatives, etc.) were included in the data set. For trademarks, we use the date in which they are filed at the USPTO. This is when information is revealed to the market and legal protection becomes enforceable if the trademark is subsequently granted. In fact, using grating dates does not produce statistically significant coefficients.

Table 1a shows the basic statistics and the results of the ordinary least squares (OLS) robust regression of (1) for different event windows (11 days, 7 days, 3 days, and same day). Coefficients for the dummy events are daily excess returns because of the corresponding event. Interesting enough, they 
become statistically insignificant as we enlarge the event window, suggesting that the effect of the event concentrates mostly in the event day, without significant anticipation, or delays in market reaction.

Results for the smaller event windows support our hypotheses: The introduction of a new product by the rival decreases the financial market value of the firm, whereas a new filed trademark increases it. A firm's own product releases and filed trademarks have positive and significant coefficients. This is in line with most of the existing literature (Bayus et al. 2003, Rao et al. 2004, Srinivasan et al. 2009). The Fama and French's (1992) indices show also the expected signs, positive for the small versus big capitalization index, negative for the high versus low book/price ratio index, and positive for the beta index.

To appreciate the monetary magnitude of the effects, we use the three-day window estimates to compute U.S. dollars changes in firm market capitalization because of an event. See that Table $1 b^{\prime}$ 's effects are sizable (in absolute terms), although small in terms of total market capitalization of the two firms.

\subsection{A Tobin's q Analysis}

Our aim here is to further corroborate the findings from the event study approach. Tobin's q analysis is the most widely used approach to estimate the value of intangible assets (especially in the form of patents) from the estimation of the market value equation (Hall et al. 2005, McGahan and Silverman 2006, Ceccagnoli 2008). Tobin's q is a forward-looking measure providing market-based views of investor expectations of the firm's future profit potential. In marketing studies, Simon and Sullivan (1993) use Tobin's q to measure brand equity, and Rao et al. (2004) investigate the relationship between manifest branding strategy and the intangible value of a corporation through a Tobin's q equation. We take data of Coca-Cola and Pepsi on a monthly basis during the period January 1999-December 2003. We have therefore 60 observations per firm, and 120 observations in total. We choose a monthly interval because it is the smallest interval available to produce still reliable enough econometric results in the form of a Tobin's q regression. ${ }^{8}$

Tobin's $\mathrm{q}$ is defined as the firm's financial market value per dollar of replacement costs of tangible assets. Firm financial market value equals outstanding shares times share price plus book value of longterm debt and net current liabilities. On a monthly scale, we take both the monthly average of the daily closing share prices and that of the outstanding shares. Replacement cost of tangible assets is the

${ }^{8}$ A quarter regression produces qualitatively similar results. sum of book value of inventory and net value of physical plant and equipment. We follow McGahan (1999) to calculate it. Data are from the U.S. Securities and Exchange Commission (SEC) filings. Because accounting data change every four months only, we use linear interpolation to assign a change to each month. Although this might sound like a limitation, one needs to keep in mind that more than $90 \%$ of the variability of Tobin's $q$ is because of the variability of the numerator, not the denominator.

We run a Tobin's q regression in which we use as core covariates the number of rival new product announcements (Productrival) and that of rival filed trademarks (TRADEMARKRIVAL). As controls, we include first both the number of a firm's new product announcements (ProductFirm) and that of its filed trademarks (TRADEMARKFIRM). ${ }^{9}$ Second, we introduce the same controls as in Rao et al. (2004). Precisely, we insert three measures obtained from SEC filing financial accounts: Operating MARGIN (net income divided by sales), LEVERAGE (long-term debt divided by total assets), and SALES GROWTH (compounded monthly sales growth rate over the previous three months). Third, we control for the monetary efforts in advertising and R\&D by using, respectively, the ratio between advertising expenditures and sales (ADVERTISING INTENSITY), and that between R\&D expenditures and sales (R\&D InTENSITY). Forth, we introduce a dummy firm (Dummy FIRM) that takes the value of one for Pepsi and zero for Coca-Cola. Fifth, to account for the effect of competition by other firms, including private labels, we use the Herfindahl index (INDUSTRY CONCENTRATION) over firms' market shares in the CSD industry (data from Beverage Digest, http://www.beverage-digest.com). Finally, to control for a firm's activity in other businesses, we add the number of product announcements in nonCSD markets (ОтнERPRODUCT). These product introductions are also taken from Infotrac's Promt. When data are not available on a monthly scale, we use linear interpolation to simulate them. ${ }^{10}$

\footnotetext{
${ }^{9}$ It is possible that both product introductions and trademark filings follow a common strategy that also encompasses a firm's response to the moves of its rival. This might suggest the presence of endogeneity in our core independent variables. To tackle this problem, we resort to instrumental variable techniques. Specifically, we use as instruments for the number of product announcements and new trademarks the lagged variables (one-month lag) of Coca-Cola and Pepsi's product announcements and new trademarks. Results, available from the authors upon request, remain qualitatively unchanged.

${ }^{10}$ We run several robustness checks. We introduce as a covariate a time trend to see whether our results are guided by some unobserved linear trend in the dependent variable for the sample period. We introduce a multiplicative term (insignificant) among our core variables. We include the one month lag Tobin's q to
} 
Table 2 Robust OLS Estimation of the Tobin's q Equation

\begin{tabular}{|c|c|c|c|c|}
\hline Variable & Mean & Std. dev. & Model 1 & Model 2 \\
\hline PRODUCTRIVAL & 1.325 & 1.572 & & $\begin{array}{c}-1.607^{* *} \\
(0.253)\end{array}$ \\
\hline TRADEMARKRIVAL & 2.675 & 4.203 & & $\begin{array}{c}0.576^{* *} \\
(0.179)\end{array}$ \\
\hline PRODUCTFIRM & 1.325 & 1.572 & & $\begin{array}{c}0.780^{*} \\
(0.436)\end{array}$ \\
\hline TRADEMARKFIRM & 2.675 & 4.203 & & $\begin{array}{l}3.244^{* *} \\
(0.455)\end{array}$ \\
\hline \multicolumn{5}{|l|}{ Controls } \\
\hline Operating Margin & 0.408 & 0.144 & $\begin{array}{c}-3.425 \\
(2.377)\end{array}$ & $\begin{array}{c}0.439 \\
(0.717)\end{array}$ \\
\hline LEVERAGE & 0.1639 & 0.091 & $\begin{array}{c}-1.680^{* *} \\
(0.435)\end{array}$ & $\begin{array}{c}-0.009 \\
(0.179)\end{array}$ \\
\hline SALES GROWTH & -0.030 & 0.247 & $\begin{array}{l}1.734^{* *} \\
(0.863)\end{array}$ & $\begin{array}{c}-0.046 \\
(0.256)\end{array}$ \\
\hline ADVERTISING INTENSITY & 0.170 & 0.026 & $\begin{array}{c}3.694 \\
(3.636)\end{array}$ & $\begin{array}{r}1.260^{*} \\
(0.722)\end{array}$ \\
\hline R\&D INTENSITY & 0.096 & 0.019 & $\begin{array}{c}6.493^{* *} \\
(2.825)\end{array}$ & $\begin{array}{c}1.247 \\
(1.265)\end{array}$ \\
\hline INDUSTRY CONCENTRATION & 0.164 & 0.001 & $\begin{array}{l}-5.568 \\
(30.054)\end{array}$ & $\begin{array}{l}-1.921 \\
(10.511)\end{array}$ \\
\hline Dummy FIRM & 0.500 & 0.550 & $\begin{array}{r}3.481^{*} \\
(1.976)\end{array}$ & $\begin{array}{c}0.581 \\
(0.662)\end{array}$ \\
\hline OTHERPRODUCTS & 1.144 & 0.946 & $\begin{array}{c}-0.440 \\
(0.359)\end{array}$ & $\begin{array}{c}-0.018 \\
(0.151)\end{array}$ \\
\hline CONSTANT & & & $\begin{array}{c}0.432 \\
(56.733)\end{array}$ & $\begin{array}{c}2.579 \\
(19.809)\end{array}$ \\
\hline Observations & & & 120 & 120 \\
\hline$R^{2}$ & & & 0.33 & 0.91 \\
\hline Adj. $R^{2}$ & & & 0.30 & 0.90 \\
\hline
\end{tabular}

Notes. Robust Huber-White estimator of variance. Log-scale regression.

${ }^{*} 0.1$ significance; ${ }^{* *} 0.05$ significance.

Table 2 shows that the main findings from the event study are confirmed. Indeed, Productrival has a negative effect on a firm's Tobin's q, whereas TRADEMARKRIVAL has a positive and significant effect. As above, Productrirm and Trademarkfirm show positive and significant coefficients. Most of the control variables have the expected signs, however, they are barely significant when we introduce the product and trademark covariates.

An alternative approach to understand the behaviour of financial markets is to look at the market response to unanticipated changes. To this end, we follow Mizik and Jacobson (2003) to operationalize deviations of the series from what could have been predicted on the basis of past information as the residual of an autoregressive model of lag 1 . We use the Poisson model for our count variables (product announcements and trademarks) and a standard

avoid unit root bias in our estimates. Results hold qualitatively unchanged. Findings are weaker, but still with the expected signs, when we pool together CSD and non-CSD product announcements and trademarks.
OLS for return on assets. The dependent variable is the cumulative abnormal returns of firm $i$ in period $t$. Results (available from the authors upon request) are weakly confirmed for rival product announcements and for the own effect of filed trademarks, but coefficients are not statistically significant for the other core variables. Interesting enough, when we look at the time series of product announcements and trademarks we cannot find evidence of any strong autocorrelation. This would explain the insignificant coefficients and would suggest that these events are difficult to predict from previous period behaviours. The high nonlinearity of the Poisson model also makes this estimation less reliable compared to the event study and the Tobin's q regression.

\subsection{Market Share and Market Size Dynamics}

As a final step, we investigate how the variables of theoretical interest affect the distribution of market shares and total demand, and, in turn, how these latter relate to a firm's Tobin's q. To this end, we propose the following generalized method of moments (GMM) estimation:

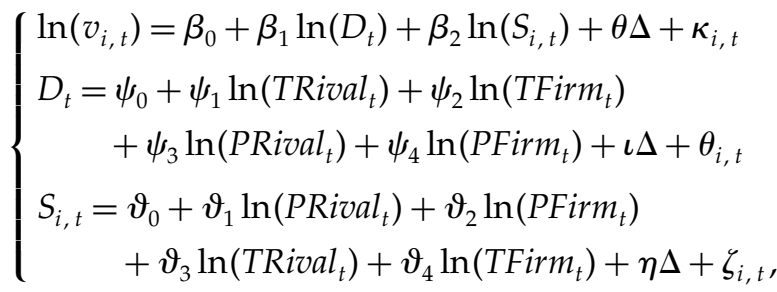

where subscript $i \neq j$ stands for Coca-Cola or Pepsi. The first equation relates the Tobin's $\mathrm{q}\left(v_{i, t}\right)$ with the total demand for CSD at period $t\left(D_{t}\right)$ and firm $i$ 's market share in period $t\left(S_{i, t}\right)$ along with controls $(\Delta)$. This equation is inefficient because $D_{t}$ and $S_{i, t}$ are endogenous variables that produce heteroscedastic residuals. Thus the GMM first estimates $D_{t}$ and $S_{i, t}$ using as core instruments new product announcements and new filed trademarks of firm $i$ and its rival $j$. A GMM estimation is well suited because it controls for potential correlation across residuals and for possible heteroscedasticity.

Total demand $D_{t}$ and firm $i^{\prime}$ s market share $S_{i, t}$ are obtained from Beverage Digest (http://www.beveragedigest.com), which publishes the annual number of 192-ounce cases sold by each firm in the market (one case equals 1.5 gallons). We use linear interpolation to insert monthly data, obtaining our proxy for $D_{t}$ and for $S_{i, t}$. As exogenous control variables, we employ the same controls of the Tobin's q estimation in $\S 4.3 .^{11}$

\footnotetext{
${ }^{11}$ We do not include Operating Margin and Sales Growth because they are highly correlated with total demand and market share. However, including these controls does not change the coefficients of our core variables.
} 
Table 3

GMM Regression, Tobin's q Estimation of Equation (2)

\begin{tabular}{|c|c|c|c|c|c|}
\hline \multirow[b]{2}{*}{ Variable } & \multirow[b]{2}{*}{ Mean } & \multirow[b]{2}{*}{ Std. dev. } & Model 1 & Model 2 & Model 3 \\
\hline & & & \multicolumn{3}{|c|}{$Y=v_{i, t}$} \\
\hline$v_{i, t}$ & 3.880 & 2.720 & & & \\
\hline DEMAND $_{t}$ & 631.200 & 6.302 & $\begin{array}{l}11.766^{* *} \\
(2.735)\end{array}$ & $\begin{array}{l}12.834^{* *} \\
(4.255)\end{array}$ & $\begin{array}{l}12.753^{* *} \\
(4.714)\end{array}$ \\
\hline MARKETSHARE $_{i, t}$ & 0.501 & 0.083 & $\begin{array}{l}4.322 * * \\
(1.254)\end{array}$ & $\begin{array}{l}3.242 * * \\
(0.154)\end{array}$ & $\begin{array}{l}4.154^{* *} \\
(1.656)\end{array}$ \\
\hline \multicolumn{6}{|l|}{ Controls } \\
\hline AdVERTISING INTENSITY & 0.170 & 0.026 & $\begin{array}{l}0.769 * * \\
(0.205)\end{array}$ & $\begin{array}{c}0.494^{*} \\
(0.262)\end{array}$ & $\begin{array}{c}0.329 \\
(0.291)\end{array}$ \\
\hline R\&D INTENSITY & 0.096 & 0.019 & $\begin{array}{c}0.432 \\
(0.358)\end{array}$ & $\begin{array}{c}0.586 \\
(0.544)\end{array}$ & $\begin{array}{c}0.413 \\
(0.462)\end{array}$ \\
\hline LEVERAGE & 0.163 & 0.091 & $\begin{array}{c}-0.142^{* *} \\
(0.014)\end{array}$ & $\begin{array}{c}-0.203^{* *} \\
(0.013)\end{array}$ & $\begin{array}{c}-0.213^{* *} \\
(0.007)\end{array}$ \\
\hline INDUSTRY CONCENTRATION & 0.164 & 0.001 & $\begin{array}{c}-0.043 \\
(0.453)\end{array}$ & $\begin{array}{c}-0.085 \\
(0.197)\end{array}$ & $\begin{array}{c}-0.066 \\
(0.445)\end{array}$ \\
\hline OTHERPRODUCT $T_{i, t}$ & 1.144 & 0.946 & $\begin{array}{c}0.133 \\
(0.903)\end{array}$ & $\begin{array}{c}0.216 \\
(0.383)\end{array}$ & $\begin{array}{c}0.317 \\
(0.476)\end{array}$ \\
\hline \multirow[t]{2}{*}{ CONSTANT } & - & - & $\begin{array}{l}9.843^{* *} \\
(3.124)\end{array}$ & $\begin{array}{l}8.744^{* *} \\
(1.301)\end{array}$ & $\begin{array}{l}9.422^{* *} \\
(4.633)\end{array}$ \\
\hline & & & \multicolumn{3}{|c|}{$Y=S_{i, t}$} \\
\hline ProductRIVAL & 1.325 & 1.572 & $\begin{array}{c}-0.031^{* *} \\
(0.005)\end{array}$ & & $\begin{array}{c}-0.061^{* *} \\
(0.011)\end{array}$ \\
\hline TRADEMARKRIVAL & 2.675 & 4.203 & $\begin{array}{c}0.726 \\
(0.655)\end{array}$ & & \\
\hline PRODUCTFIRM & 1.325 & 1.572 & $\begin{array}{l}0.085 * * \\
(0.004)\end{array}$ & & $\begin{array}{l}0.049^{* *} \\
(0.006)\end{array}$ \\
\hline TRADEMARKFIRM & 2.675 & 4.203 & $\begin{array}{c}0.614 \\
(0.752)\end{array}$ & & \\
\hline \multirow[t]{2}{*}{ CONSTANT } & - & - & $\begin{array}{l}0.133^{* *} \\
(0.048)\end{array}$ & & $\begin{array}{l}0.229^{* *} \\
(0.013)\end{array}$ \\
\hline & & & \multicolumn{3}{|c|}{$Y=D_{t}$} \\
\hline ProductRIVAL & 1.325 & 1.572 & & $\begin{array}{c}1.455 \\
(0.953)\end{array}$ & \\
\hline TRADEMARKRIVAL & 2.675 & 4.203 & & $\begin{array}{l}0.222^{* *} \\
(0.003)\end{array}$ & $\begin{array}{c}0.015^{* *} \\
(0.004)\end{array}$ \\
\hline PRODUCTFIRM & 1.325 & 1.572 & & $\begin{array}{c}1.223 \\
(1.547)\end{array}$ & \\
\hline TRADEMARKFIRM & 2.675 & 4.203 & & $\begin{array}{l}1.783^{* *} \\
(0.173)\end{array}$ & $\begin{array}{c}0.064^{* *} \\
(0.003)\end{array}$ \\
\hline CONSTANT & - & - & & $\begin{array}{l}2.126^{* *} \\
(0.640)\end{array}$ & $\begin{array}{l}1.751^{* *} \\
(0.256)\end{array}$ \\
\hline \multicolumn{3}{|l|}{ EXOGENOUS CONTROLS } & \multicolumn{3}{|c|}{ Inserted always } \\
\hline Adj. $R^{2}$ & & & 0.855 & 0.743 & 0.898 \\
\hline Observations & & & 120 & 120 & 120 \\
\hline
\end{tabular}

Notes. Robust Huber-White estimator of variance. Log-scale regression.

${ }^{*} 0.1$ significance; ${ }^{* *} 0.05$ significance.

Main descriptive statistics and results of Equation (2) are reported in Table 3. The scale is logarithmic.

To correctly identify the instruments, we run first the market share equation (Model 1), then the demand equation (Model 2), and finally we show the correctly identified estimation (Model 3). Most importantly, from the instrumental regressions, we can sort out how product innovation and new advertising affect a firm's financial market value. Notice that firm $i$ 's market share $S_{i, t}$ does not depend on new filed trademarks of either firm $i$ or firm $j$ (Model 1 in Table 3). Instead, it is directly influenced by both firms' product announcements, i.e., Productrival has a negative effect and Productrirm a positive effect. By contrast, total demand $D_{t}$ depends only on new filed trademarks (Model 2 in Table 3). Both TRAdemARKRIVAL and TRAdeMARKFIRM increase $D_{t}$, whereas Productrival and Productfirm do not have a significant effect. Model 3 in Table 3 presents the results of the complete estimation, using only the instruments that show a significant coefficient in the first stage. Results are totally in line with the findings of the event study and the Tobin's q regression (Tables $1 \mathrm{a}$ and 2). ${ }^{12}$

In addition, the GMM estimation shows that product innovation and new advertising act through different channels. In a mature product market such as CSD, new advertising boosts total industry demand and/or increases entry barriers, so that rival filed trademarks have a positive spillover on a firm's financial market value. Incremental product innovation is a more aggressive strategic weapon that directly affects market shares, implying a negative impact on firm $i^{\prime}$ financial market value.

\section{Conclusion and Discussion}

Although there is growing literature attempting to investigate how different marketing actions affect a firm's financial market value (i.e., Bayus et al. 2003, Pauwels et al. 2004, Srinivasan et al. 2009), very little is known about the impact of rivals' moves. Chen et al. (2005) find that rivals' product announcements have a bigger negative impact on a firm's financial market value when product newness is limited. This is consistent with our finding for the CSD industry where most product innovations are modest or incremental. We indeed show that when Coca-Cola (Pepsi) announces a new product, Pepsi (Coca-Cola)'s market capitalization shrinks by approximately $\$ 350$ (\$650) million. On the other hand, to the best of our knowledge, this is the first study that looks at the effect of rivals' new advertising on a firm's financial market value. In this respect, our empirical finding is worth emphasizing. When Coca-Cola (Pepsi) files a new trademark, Pepsi (Coca-Cola)'s market capitalization increases by approximately $\$ 280$ (\$480) million. We argue that a combination of market expansion, increased differentiation, and stronger entry barriers, because of advertising, might explain this positive effect.

\footnotetext{
${ }^{12}$ It is worth noting that the Hansen-Sargan test of overidentification of restrictions is equal to 2.77 , with a $p$-value of 0.302 . Therefore the test does not reject the null hypothesis, ensuring that the group of instruments is not correlated with the error term.
} 
Our findings allow us to draw several implications for investors, managers, and policymakers. Shareholders who want to assess the performance of strategies proposed by the board of managers should recognize that financial models that underestimate the impacts of rival actions could produce biased forecasts.

To elaborate correct strategies, managers must disentangle the different impulses that come from the surrounding environment, especially competitors' moves. New advertising and incremental product introductions are two major loci of firm investments, and thus key areas of managerial decisions. In our view, managers have to understand not only the impact of a particular move, but also the channels through which this move acts. We show that in the CSD market advertising increases a firm's and its rival's financial market value by increasing total demand, while new product releases steal market share. Therefore, when managers decide how to divide a firm budget between R\&D and advertising, they must also keep in mind the different levels of future aggressiveness that these investments imply. Moreover, the correct timing and alternation of these two moves-adapted also to the observed rival moves-could significantly influence the firm's financial market value.

For marketing managers, one of the most interesting results of this work is the positive spillover effect of new advertising on competitors' financial market value through an increase of total demand. This result seems to fit well with the recent trend in the CSD industry toward a greater similarity of marketing approaches among competitors. Several business press articles (e.g., Devaney 2002) have recognized that both Pepsi and Coca-Cola seem to have shifted their marketing strategies from brand consolidation to more generic advertising. This similarity could be an explanation for the effect on market size dynamics that we discover.

Policymakers and antitrust analysts could benefit from this study by noting that some firm investments may have a collusive effect. Novel detailed investigations, particularly on the role of advertising in oligopolistic mature product markets, could shed new light on the extent to which promotion is used to increase entry barriers and to consolidate dominant positions.

The paper has a number of limitations that we hope can be addressed in future research. We assumed in our empirical exercise that the price remains constant during the period under study. Although this is a fairly reasonable assumption in the CSD market, controlling for price announcements and price promotions would definitely improve the robustness of our findings. Although Coca-Cola and Pepsi still rely heavily on the CSD industry, they have tried to diversify away in other related businesses. Most importantly, these companies have a large fraction of their sales from international markets. We try to control as well as we can for these additional sources of heterogeneity in our data. However, non-CSD and international markets might need to be addressed separately because they might involve idiosyncratic marketing actions and different competitive conditions. Finally, extending this research to other mature industries would increase our confidence in the generalizability of the main findings.

\section{Acknowledgments}

The authors thank G. Ahuja, R. Chandy, W. Cohen, K. L. Hui, R. Oriani, A. Torres, an associate editor, two anonymous reviewers of Management Science, and seminar participants at Boston University (School of Management), University Pompeu Fabra (Barcelona), University of Bologna, Copenhagen Business School, University Carlos III (Madrid), the 2008 Duke Strategy Conference, the 2008 DRUID Winter Conference (Aalborg), the 2007 Academy of Management Conference (Philadelphia), and the 2nd EIASM Co-opetition Conference (Bocconi University) for comments and suggestions on an earlier draft. Financial support from the Fundación Ramón Areces and the Spanish Ministry of Education (SEJ2007-30286-E and SEJ2005-06655) is gratefully acknowledged. The usual disclaimer applies.

\section{References}

Aboulnasr, K., O. Narasimhan, E. Blair, R. Chandy. 2008. Competitive response to radical product innovations. J. Marketing $\mathbf{7 2}$ 94-110.

Andrews, J., D. C. Smith. 1996. In search of the marketing imagination: Factors affecting the creativity of marketing programs for mature products. J. Marketing Res. 33(2) 174-187.

Austin, D. H. 1993. An event study approach to measuring innovative output: The case of biotechnology. Amer. Econom. Rev. 83(2) 253-258

Bass, F. M., A. Krishnamoorthy, A. Prasad, S. P. Sethi. 2005. Generic and brand advertising strategies in a dynamic duopoly. Marketing Sci. 24(4) 556-568.

Bayus, B. L., W. P. Putsis. 1999. Product proliferation: An empirical analysis of product line determinants and market outcomes. Marketing Sci. 18(2) 137-153.

Bayus, B. L., G. Erickson, R. Jacobson. 2003. The financial rewards of new product introductions in the personal computer industry. Management Sci. 49(2) 197-210.

Berndt, E. R., T. M. Bui, D. H. L. Lucking-Reiley, G. L. Urban. 1997. The roles of marketing, product quality, and price competition in the growth and composition of the U.S. antiulcer drug industry. T. F. Bresnahan, R. J. Gordon, eds. The Economics of New Goods. University of Chicago Press, Chicago, 277-322.

Ceccagnoli, M. 2008. Appropriability, preemption, and firm performance. Strategic Management J. Forthcoming.

Champsaur, P., J. C. Rochet. 1989. Multiproduct duopolist. Econometrica 57(3) 533-557.

Chandler, A. D. 1994. The competitive performance of U.S. industrial enterprises since the Second World War. Bus. History Rev. 68 1-72. 
Chaudhuri, A., M. B. Holbrook. 2001. The chain of effects from brand trust and brand affect to brand performance: The role of brand loyalty. J. Marketing 65(2) 81-93.

Chen, M. J., I. C. MacMillan. 1992. Non-response and delayed response to competitive move: The role of competitor dependence and action irreversibility. Acad. Management J. 35(3) 539-570.

Chen, S. S., K. W. Ho, K. H. Ik. 2005. The wealth effect of new product introductions on industry rivals. J. Bus. 78(3) 969-996.

Cheng, C. S., J. P. Chen. 1997. Firm valuation of advertising expense: An investigation of scale effects. Managerial Finance 23(10) 41-62.

Conner, K. R. 1998. Strategies for product cannibalism. Strategic Management J. 19 9-26.

Das, S., P. K. Sen, S. Sengupta. 1998. Impact of strategic alliances on firm valuation. Acad. Management J. 41(1) 27-41.

Devaney, P. 2002. Soft drinks giants face battle for individuality. Marketing Week 26(17) 26-28.

Dubé, J.-P. 2004. Multiple discreteness and product differentiation: Demand for carbonated soft drinks. Marketing Sci. 23(1) 66-81.

Erickson, G., R. Jacobson. 1992. Gaining comparative advantage through discretionary expenditures: The returns to R\&D and advertising. Management Sci. 38(9) 1264-1279.

Fama, E. F., K. R. French. 1992. The cross-section of expected stock returns. J. Finance 47(2) 427-465.

Friedman, H. H., L. Friedman. 1976. Advertising myopia. J. Advertising 5(2) 29-31.

Hall, B. H., A. Jaffe, M. Trajtenberg. 2005. Market value and patent citations. RAND J. Econom. 36(1) 16-38.

Kadiyali, V., N. Vilcassim, P. Chintagunta. 1999. Product line extensions and competitive market interactions: An empirical analysis. J. Econometrics 89(1-2) 339-363.

Kekre, S., K. Srinivasan. 1990. Broader product line: A necessity to achieve success. Management Sci. 36(10) 1216-1231.

Krishnamurthy, S. 2000. Enlarging the pie vs. increasing one's slice: An analysis of the relationship between generic and brand advertising. Marketing Lett. 11(4) 37-48.

Krishnamurthy, S. 2001. The effects of provision points on generic advertising funding. Marketing Lett. 12(3) 315-325.

Lancaster, K. M. 1984. Brand advertising competition and industry demand. J. Advertising 13(4) 19-30.

Lane, V., R. Jacobson. 1995. Stock market reactions to brand extension announcements: The effects of brand attitude and familiarity. J. Marketing 59(1) 63-77.

Mahajan, V., S. Sharma, R. Buzzel. 1993. Assessing the impact of competitive entry on market expansion and incumbent sales. J. Marketing 57 39-52.

McGahan, A. M. 1999. The performance of U.S. corporations: 1981-1994. J. Industrial Econom. 47(4) 373-398.
McGahan, A. M., B. S. Silverman. 2006. Profiting from technological innovation: The effect of competitor patenting on firm value. Res. Policy 35(8) 1222-1242.

Mendonca, S., T. Pereira, T. Santos, G. M. Mira. 2004. Trademarks as an indicator of innovation and industrial change. Res. Policy 33(9) 1385-1404.

Mizik, N., R. Jacobson. 2003. Trading off between value creation and value appropriation: The financial implications of shifts in strategic emphasis. J. Marketing 67 63-76.

Neslin, S. A., S. Gupta, W. Kamakura, J. X. Lu, C. H. Mason. 2006. Defection detection: Measuring and understanding the predictive accuracy of customer churn models. J. Marketing Res. 43(2) 204-211.

Nguyen, D., L. Shi. 2006. Competitive advertising and market-size dynamics: A research note on theory and evidence. Management Sci. 52(6) 963-973.

Ofek, E., M. Sarvary. 2003. R\&D, marketing, and the success of next-generation products. Marketing Sci. 22(3) 355-370.

Parsons, L. J. 1975. The product life cycle and the time-varying advertising elasticities. J. Marketing Res. 12(4) 476-480.

Pauwels, K., J. Silva-Risso, S. Srinivasan, D. M. Hanssens. 2004. New products, sales promotions and firm value, with application to the automobile industry. J. Marketing 68 142-156.

Pennings, J. M., F. Harianto. 1992. The diffusion of technological innovation in the commercial banking industry. Strategic Management J. 13(1) 29-46.

Rao, V. R., M. K. Agarwal, D. Dahloff. 2004. How is manifest branding strategy related to the intangible value of a corporation? J. Marketing 68 126-141.

Seethamraju, C. 2003. The value relevance of trademarks. J. R. M. Hand, B. Lev, eds. Intangible Assets: Values, Measures, and Risks. Oxford University Press, Oxford, UK, 228-247.

Shaffer, G., Z. J. Zhang. 2002. Competitive one-to-one promotions. Management Sci. 48(9) 1143-1160.

Simon, C. J., M. W. Sullivan. 1993. The measurement and determinants of brand equity: A financial approach. Marketing Sci. 12(1) 28-52.

Srinivasan, S., K. Pauwels, J. Silva-Risso, D. M. Hanssens. 2009. Product innovations, advertising, and stock returns. J. Marketing 73(1) 24-43.

Sutton, J. 1998. Technology and Market Structure. MIT Press, Cambridge, MA.

Tellis, G. J., C. Fornell. 1988. The relationship between advertising and product quality over the product life cycle: A contingency theory. J. Marketing Res. 25(1) 64-71.

Upshaw, E. 1995. An economist's view of research on term limits. Soc. Sci. Quart. 76(4) 730-733.

Wall Street Journal, The. 2005. Coke to debut "Real" ad on "Idol." (January 17) 14.

Yoffie, D. 2007. Cola wars continue: Coke and Pepsi in 2006. HBS Case 9-706-447, Harvard Business School, Boston. 